\title{
Hsp-27 expression at diagnosis predicts poor clinical outcome in prostate cancer independent of ETS-gene rearrangement
}

\author{
CS Foster, , , AR Dodson', L Ambroisine ${ }^{2}$, G Fisher ${ }^{2}$, H Møller ${ }^{3}$, J Clark ${ }^{4}$, G Attard ${ }^{4}$, J De-Bono ${ }^{4}$, P Scardino ${ }^{5}$, \\ VE Reuter ${ }^{5}$, CS Cooper ${ }^{4}$, DM Berney ${ }^{6}$ and J Cuzick ${ }^{2}$ on behalf of the Trans-Atlantic Prostate Group \\ 'Division of Cellular Pathology and Molecular Genetics, University of Liverpool, Duncan Building, Daulby Street, Liverpool L69 3GA, UK; ${ }^{2}$ Cancer Research \\ UK Centre for Epidemiology, Mathematics and Statistics Wolfson Institute of Preventive Medicine, Queen Mary University of London, Charterhouse \\ Square, London ECIM 6BQ, UK; ${ }^{3}$ King's College London, Thames Cancer Registry, 42 Weston Street, London SEI 3QD, UK; ${ }^{4}$ Institute of Cancer \\ Research, Male Urological Cancer Research Centre, 15 Cotswold Road, Belmont, Sutton, Surrey SM2 5NG, UK; 5 Departments of Urology and Pathology, \\ Memorial Sloan Kettering Cancer Center, 1275 York Avenue, New York, NY 1002 I, USA; ${ }^{T}$ The Orchid Tissue Laboratory, Centre for Molecular Oncology, \\ Barts and The London School of Medicine and Dentistry, London EI 2AD, UK
}

BACKGROUND: This study was performed to test the hypothesis that expression of small heat shock protein Hsp- 27 is, at diagnosis, a reliable predictive biomarker of clinically aggressive prostate cancer.

METHODS: A panel of tissue microarrays constructed from a well-characterised cohort of 553 men with conservatively managed prostate cancer was stained immunohistochemically to detect Hsp-27 protein. Hsp-27 expression was compared with a series of pathological and clinical parameters, including outcome.

RESULTS: Hsp-27 staining was indicative of higher Gleason score $(P<0.001)$. In tissue cores having a Gleason score $>7$, the presence of Hsp-27 retained its power to independently predict poor clinical outcome $(P<0.002)$. Higher levels of $\mathrm{Hsp}-27 \mathrm{staining}$ were almost entirely restricted to cancers lacking ERG rearrangements $\left(\chi^{2}\right.$ trend $\left.=31.4, P<0.001\right)$, although this distribution did not have prognostic significance.

INTERPRETATION: This study has confirmed that, in prostate cancers managed conservatively over a period of more than I5 years, expression of $\mathrm{Hsp}-27$ is an accurate and independent predictive biomarker of aggressive disease with poor clinical outcome $(P<0.00 \mathrm{I})$. These findings suggest that apoptotic and cell-migration pathways modulated by Hsp-27 may contain targets susceptible to the development of biologically appropriate chemotherapeutic agents that are likely to prove effective in treating aggressive prostate cancers.

British Journal of Cancer (2009) I 0 I, | |37- | |44. doi: |0.1038/sj.bjc.6605227 www.bjcancer.com

Published online 25 August 2009

(c) 2009 Cancer Research UK

Keywords: heat shock protein 27; prostate cancer; prognostic biomarker

Biologically and behaviourally, prostate cancer is a heterogeneous malignant disease (Foster et al, 2002). In the USA, in 2008, there were 186,320 new cases of prostate cancer and 28660 deaths from this disease (Jemal et al, 2008). Equivalent figures from the United Kingdom reveal that 34,302 new cases were diagnosed in 2005 and that 10000 men died of prostate cancer (http://info.cancerresearchuk.org/ cancerstats/types/prostate/). Globally, prostate cancer is currently the fifth commonest malignancy and the most common in men, with more than 679000 new cases estimated to have occurred in 2002 (Parkin et al, 2005). The clinical potential of an individual prostate cancer may range from relative indolence to highly aggressive, with progression occurring rapidly. Hence, there is an urgent requirement to develop reliable biomarkers that can accurately stratify prostate cancer at diagnosis and segregate men with aggressive cancers requiring urgent treatment from

*Correspondence: Professor CS Foster, Division of Cellular Pathology and Molecular Genetics, School of Cancer Studies, University of Liverpool, 6th Floor, Duncan Building, Daulby Street, Liverpool L69 3GA, UK; E-mail: csfoster@liv.ac.uk

Received 3 April 2009; revised 2 July 2009; accepted 9 July 2009; published online 25 August 2009 those who may be managed conservatively. Thus far, the only two parameters generally accepted to be valuable in the clinical management of prostate cancer are serum PSA and Gleason score following histopathological assessment of prostatic biopsy specimens. Although the extent of disease is more useful than clinical stage at diagnosis, and retains a low level of significance in multivariate analysis, neither of these are of clinical utility and are significantly inferior to Gleason score and PSA (Cuzick et al, 2006). Although both approaches have been clinically valuable, neither provides accurate predictive information with respect to individual prostate cancers.

Hsp-27 was originally discovered as an oestrogen-modulated protein in breast cancer (Adams et al, 1983), and thereafter identified to contribute to apoptosis (Tenniswood et al, 1992) and as a potential prognostic marker in prostate cancer cells (Morino et al, 1997). The functional relationship between Hsp-27, encoded by the gene $H S P B 1$ located on human chromosome 7 at q11.23, and behavioural phenotype was suggested in the preliminary study that showed Hsp-27 expression to predict $(P<0.0001)$ death from prostate cancer (Cornford et al, 2000). However, the cohort was heterogeneous and the sample size relatively small. In contrast, the current study has allowed a rigorous assessment of Hsp-27 
expression in a large cohort of well-characterised and conservatively managed patients (Cuzick et al, 2006) with respect to the prediction of tumour aggression. Our original observation that Hsp-27 predicts clinical recurrence in prostate cancer was supported by the finding from a subsequent study that the protein level increases after androgen ablation and is cytoprotective in hormone-refractory prostate cancer (Rocchi et al, 2004), and, more recently, by two studies on men undergoing radical prostatectomy (Glaessgen et al, 2008; Miyake et al, 2008).

The value of Hsp-27 expression as a predictive biomarker is not restricted to prostate cancer. In developing breast neoplasia, modulation of Hsp-27 in early proliferative lesions (O'Neill et al, 2003) occurs synchronously with that of ER-alpha to predict subsequent development of breast malignancy $(P<0.001)$. However, in established node-positive breast cancer, Hsp-27 does not predict survival (Tetu et al, 1995). In cervical neoplasia, association has been reported between over-expression of Hsp-27 and grade, although no survival data were included (Ono et al, 2009). With respect to treatment of malignant disease, increased expression of Hsp-27 has been linked to vincristine resistance in gastric cancer (Yang et al, 2009) and to 5-fluorouracil resistance in colon cancer (Tsuruta et al, 2008), and breast cancer cells initially overexpressing Hsp-27 became sensitive to doxorubicin after modulation of endogenous Hsp-27 levels by paclitaxel (Shi et al, 2008).

Prostate cancers often contain an ETS-gene fusion that involves the androgen-regulated promoter regions from the TMPRSS gene (chromosome 21q22.3) and joins to $3^{\prime}$ ERG sequences (Tomlins et al, 2005). These translocations are common in established prostate cancer (Clark et al, 2007, 2008) and have been identified in PIN, but with a lower frequency (Cerveira et al, 2006; Perner et al, 2007; Mosquera et al, 2008). Taken together with evidence from transgenic mouse studies (Tomlins et al, 2008), these observations suggest that TMPRSS-ERG fusion alone may be insufficient for transformation from benign to malignant prostatic epithelium. However, the biological activity of alternatively spliced TMPRSS2 ERG fusion gene transcripts is pleiotropic (Wang et al, 2008), with the consequential effects on the emerging phenotypes of the involved neoplastic cells (initiation $v s$ progression) depending on the corresponding rearrangement (Carver et al, 2009).

To test the hypothesis that Hsp-27 expression is a reliable predictive biomarker of clinically aggressive prostate cancer, we analysed an extensive set of tissue microarrays (TMAs) constructed from the archived diagnostic tissues obtained by the Transatlantic Prostate Group following interrogation of 6 UK Cancer Registries (Cuzick et al, 2006). This cohort of patients, with a detailed clinical follow-up extending over 15 years, has provided an opportunity to assess the time over which Hsp-27 expression might have predictive accuracy. As we had already utilised this cohort to confirm the predictive power of ETS-gene alterations, we were able to assess the relationship between ETS-gene status and Hsp-27 expression.

\section{MATERIALS AND METHODS}

\section{Patient cohort}

To help identify and optimise markers that may be of use in the treatment of men with prostate cancer, we recently established a retrospective cohort of men who were managed only conservatively (Cuzick et al, 2006; Eastham et al, 2008). Improving on previous studies (Chodak et al, 1992; Albertsen et al, 1995, 2005; Adolfsson et al, 1997; Holmberg et al, 2002; Johansson et al, 2004; Bill-Axelson et al, 2005), our analyses included centrally assigned Gleason scores determined by modern grading criteria and allowed comparisons with several additional clinical parameters. In agreement with Johansson et al (2004) and Albertsen et al (2005), we found Gleason score to be an important determinant of cancer-specific mortality, but baseline PSA and, to a lesser extent, stage of disease added further predictive value. Tissue microarrays were constructed from an unselected transurethral resection of the prostate specimens taken from patients who had received no initial treatment in a cohort of conservatively managed men with prostate cancer. Men who had had hormone therapy before diagnostic biopsy were also excluded, because of the influence of hormone treatment in the interpretation of Gleason grade (Cuzick et al, 2006).

Tissue micro-arrays for Hsp-27 analysis and for ETS-rearrangement FISH studies The original haematoxylin and eosin (H\&E)-stained diagnostic tissues for all cases included in this study were reviewed by a panel of three urological pathologists (DMB, CSF and VER) as previously described to confirm each diagnosis of prostate cancer and to exclude all false positives (Berney et al, 2007b). Of the total number of cases reviewed, 133 (7\%) were reassigned a nonmalignant diagnosis and thereafter excluded. The remaining 1656 cases were further reviewed to confirm and standardise the Gleason score according to conventional criteria (Deshmukh and Foster, 1997). For those 1656 cases of cancer, there was a significant reassignment in the Gleason score across a wide spectrum, yielding a more accurate predictor of prognosis than the original scores in multivariate analysis (Berney et al, 2007a). Following mark-up of the tissue sections to identify the predominant patterns of prostate cancer and of non-malignant glandular epithelium, TMAs were constructed in $35 \times 22 \times 7 \mathrm{~mm}^{3}$ blocks of Lamb paraffin wax using a manual tissue microarrayer (Beecher Instruments, Sun Prairie, WI, USA). Up to four cores of $600 \mu \mathrm{m}$ diameter were taken from each prostatic tissue. Reassignment of areas of cancer or non-malignant epithelium in each core was performed by histopathological examination of $\mathrm{H} \& \mathrm{E}-$ and $\mathrm{p} 63 /$ AMACR-stained sections that flanked the TMA slice used for FISH studies. The morphological criteria for selection of 'normal' and 'malignant' prostatic epithelium conformed to previously published definitions (Foster, 2000; Foster et al, 2000, 2004). FISH studies to detect ERG and ETV1 gene re-arrangements were conducted as described previously (Attard et al, 2008a,b).

Ethical approval Approval for the collection of the cohort was obtained from the Northern Multi-Research Ethics Committee, followed by approval from the local ethics committee at each of the collaborating hospital trusts. This work was approved by the Clinical Research and Ethics Committee at the Royal Marsden Hospital and The Institute of Cancer Research.

Hsp-27 immunohistochemistry A mouse monoclonal antibody to Hsp-27 was purchased from Leica Microsystems (NCL-Hsp-27 Leica Microsystems Newcastle Ltd, Newcastle Upon Tyne, UK). The ADVANCE Autostainer Universal Staining System, rabbit/ mouse HRP was purchased from Dako (K4068, Dako UK Ltd, Ely, Cambridge, UK). High-temperature antigen retrieval was performed using a domestic stainless-steel pressure cooker at full pressure for $3 \mathrm{~min}$ in $10 \mathrm{~mm}$ EDTA solution ( $\mathrm{pH} \mathrm{7.0)}$. The Hsp-27 antibody was diluted in REAL Antibody Diluent (S2022, Dako UK Ltd) to $1: 50$. Sections of each specimen, of $4 \mu \mathrm{m}$ thickness, were cut onto amino-propyl tri-ethoxysilane-coated glass slides and dried overnight in an oven at $56{ }^{\circ} \mathrm{C}$. For staining, slides were dewaxed with xylene, followed by rehydration through graded ethanols. Endogenous peroxidase activity was blocked by immersion in a $3 \%(\mathrm{w} / \mathrm{v})$ solution of $\mathrm{H}_{2} \mathrm{O}_{2}$ in methanol for $12 \mathrm{~min}$. Sections were then rinsed in tap water followed by deionised water. High-temperature antigen retrieval was performed, after which slides were transferred to an automatic immunostainer (Autostainer Plus, Dako UK Ltd). After equilibration in fresh TBS comprising $0.05 \mathrm{M}$ Tris ( $\mathrm{pH} 7.6$ ) containing $0.12 \mathrm{M} \mathrm{NaCI}$ and $0.05 \%$ Tween-20 (TBS-T), sections were incubated with the primary antibody for $40 \mathrm{~min}$ at room temperature, washed with TBS-T and 
incubated with ADVANCE link reagent for $20 \mathrm{~min}$ at room temperature, washed with TBS-T and incubated with ADVANCE enzyme reagent for $30 \mathrm{~min}$ at room temperature. Thereafter, sections were washed before applying a solution of 3,3'-diaminobenzidine tetrahydrochloride and $\mathrm{H}_{2} \mathrm{O}_{2}(\mathrm{DAB}+, \mathrm{K} 3468$, Dako UK Ltd) for $10 \mathrm{~min}$ to reveal sites of antibody binding. Following a rinse in deionised water, slides were removed from the Autostainer. Nuclei were counterstained with Mayer's haematoxylin before mounting the slides in DPX. For the negative control used in each experiment, the primary antibody was replaced with Antibody Diluent. All sections were scored using CSF and ARD.

Analysis of Hsp-27 expression Specimens were considered positive only if at least $5 \%$ of the epithelial cells (either normal or malignant) unequivocally expressed Hsp-27 staining. The 5\% cut-off was chosen because it conforms to the International European Organization for Research and Treatment of CancerGynaecological Cancer Cooperative Group recommendations (van Diest et al, 1997). Furthermore, this cut-off was used as the criterion to distinguish positive and negative immunohistochemical staining in our previous studies of prostate cancer (Cornford et al, 2000), thus ensuring consistency of criteria between studies. For each tissue section, staining was assessed as negative, weakly positive or only focally positive (low-level expression), or strongly positive (high-level expression), and scored as $0,1,2$ or 3 , respectively. For positive cores, the cellular distribution of Hsp staining in benign or malignant prostatic epithelium was assessed.

Statistical analyses The primary end points for this study were time to death from prostate cancer and time to death from any cause. Univariate and multivariate analyses were performed by proportional hazard (Cox) regression analysis (Cox and Oakes, 1984). All follow-up times commenced at the point of 6 months following diagnosis, as in the previous report (Cuzick et al, 2006). Associations between categorical data were examined using the $\chi^{2}$ test and Fisher's exact test when expected cell counts were less than 5. Associations between categorical and numerical variables were assessed using analysis of variance. All $P$-values were twosided. The following variables, determined as described previously (Cuzick et al, 2006), were included in the multivariate analyses: centrally reviewed Gleason score, baseline PSA (the last PSA value within 6 months of diagnosis) and age at diagnosis. Clinical stage information, which was available for $60 \%$ of the patients, was of minimal significance in this restricted series and was therefore not included.

\section{RESULTS}

\section{Hsp-27 expression in prostate tissue}

Analysis of the cores of tissues contained in the 24 blocks comprising the arrays showed that 743 patients were represented on the arrays that included 1251 cancer cores, 18 PIN, 624 non-PIN hyperplasia and 792 cores with morphologically benign tissues. The distribution of cytoplasmic Hsp-27 expression within the various morphological groups ranging from benign to malignant is presented in Figure 1. In this analysis, Hsp-27 expression was identified in $64 \%$ of the cores containing morphologically unremarkable prostatic epithelia, and in $50 \%$ of the cores of hyperplastic tissues (Figure 2). Of the 18 PIN cores only 7 (39\%) were positive, while $200(16 \%)$ of the prostate cancer cores were positive. When the data for the malignant tissues were analysed with respect to individual cases, 553 patients remained in the analysis, with $441(79.7 \%)$ of the cases being negative for Hsp-27 and $112(20.3 \%)$ of the cases showing cytoplasmic positivity. The patients' demographics and tumour characteristics, together with details of their Hsp-27 expression, are presented in Table 1. Hsp-27 expression was associated with Gleason score $(P=0.001)$, whereas no association was found with age, baseline PSA, clinical stage or extent of disease.

Overall effect of Hsp-27 Absence of Hsp-27 expression was associated with a better survival from prostate cancer (Figure 3) and overall survival. In the univariate analyses, Hsp-27 cytoplasmic positivity was a significant prognostic factor for poor survival from prostate cancer $(\mathrm{HR}=1.89,95 \% \mathrm{CI}=1.32-2.70, P<0.001)$ and overall survival $(\mathrm{HR}=1.60,95 \% \mathrm{CI}=1.26-2.05, P<0.001)$. In multivariate analyses that included Gleason score, extent of disease, baseline PSA and age at diagnosis, Hsp-27 cytoplasmic positivity remained an independent prognostic factor for poor cancer-specific survival $\left(\Delta \chi^{2}(1 \mathrm{df})=4.49, P=0.03\right)$ and overall survival $\left(\Delta \chi^{2}(1 \mathrm{df})=7.45, P=0.005\right)$.

\section{Subgroup analyses}

Analysis of Hsp-27 expression according to Gleason score: The independent prognostic significance of Hsp-27 cytoplasmic positivity for prostate cancer survival in a multivariate model was maintained in prostate cancers with Gleason score $>7$ $\left(\Delta \chi^{2}(1 \mathrm{df})=7.08, P=0.03\right.$ for prostate cancer survival $)$, but not in prostate cancers with Gleason score $7\left(\Delta \chi^{2}(1 \mathrm{df})=0.43, P=0.50\right)$ or in prostate cancers with Gleason score $<7\left(\Delta \chi^{2}(1 \mathrm{df})=0.11\right.$, $P=0.75$ ), as shown schematically in Figure 4 .

Analysis of Hsp-27 expression according to ETS-re-arrangement status: Both Hsp-27 expression and ETS (ERG and ETV1) gene status were available for 435 of the 553 patients (Table 2). When the cancers were stratified according to ETS-gene status, in multivariate analyses the presence of Hsp-27 cytoplasmic positivity failed to reach significance for prostate cancer survival in both non-rearranged ETS $\left(\Delta \chi^{2}(1 \mathrm{df})=2.35, P=0.12\right)$ and rearranged ETS status $\left(\Delta \chi^{2}(1 \mathrm{df})=0.68, P=0.40\right)$ groups. However, interrogation of the data (Table 2) revealed a significant difference in the distribution of Hsp-27 staining in the two groups $\left(\chi^{2}=18.3\right.$, $P<0.001)$. With increasing expression of Hsp-27 there was a progressive decline in ETS-gene rearrangement frequency $\left(\chi^{2}\right.$ (trend $\left.)=31.4, \quad P<0.001\right)$, such that most of the strongly staining cancers were found in ERG non-rearranged tumours.

\section{DISCUSSION}

This study has shown that, at diagnosis, Hsp-27 expression is a powerful independent predictive biomarker for survival from prostate cancer $(P<0.001)$ and for overall survival $(P<0.001)$. Using a large cohort of men gathered from across the United Kingdom over a period of more than 15 years, Hsp-27 expression was used to accurately segregate men with poor prognosis of prostate cancer and who required active treatment from those with relatively indolent disease that could be managed conservatively, with confidence. In this study, Hsp-27 expression correlated strongly with Gleason grade $(P=0.001)$, but not with baseline PSA values $(P>0.2)$, despite PSA being an independent predictive variable in the original cohort of patients. The latter observation reflects the complex relationships between $\mathrm{Hsp}-27$ and androgen receptor in the transactivation of PSA (Zoubeidi et al, 2007). The current findings also reveal that while most morphologically benign tissues strongly express Hsp-27, lower proportions of hyperplasia and PIN exhibit staining (Figure 1), suggesting that expression of the protein may be down-regulated in the in-situ neoplastic epithelial cells, which are the precursors of invasive prostate cancer (Foster et al, 2002).

There is strong evidence that Hsp-27 is an important gatekeeper of cancer cell migration and survival through differential phosphorylation and by its relative level of expression. Evidence from different cell systems indicates that Hsp-27 controls cell 
A
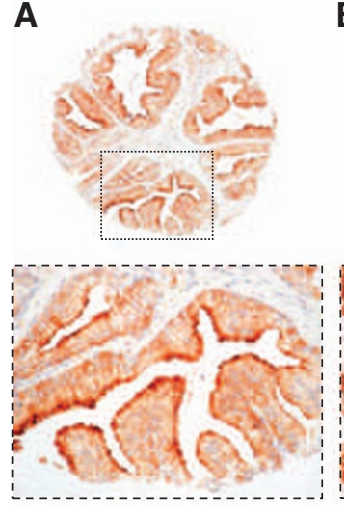

E
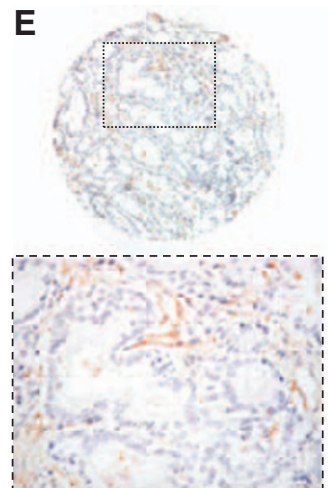

B
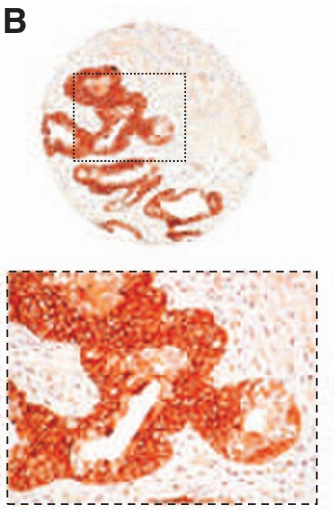

F
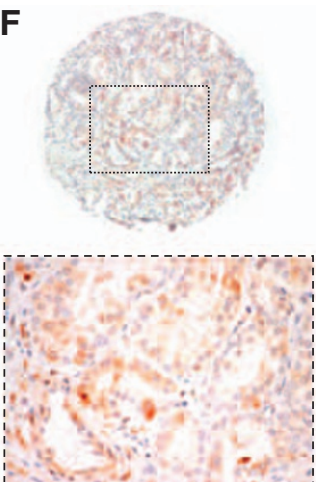

C
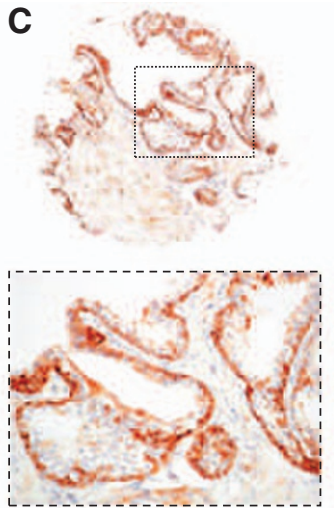

G
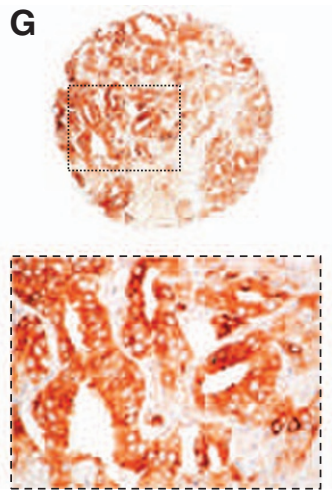

D

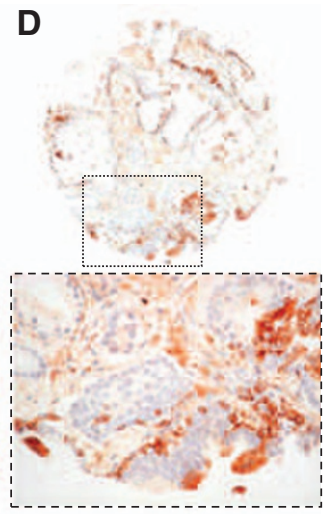

H

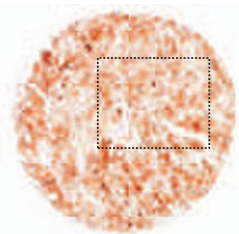

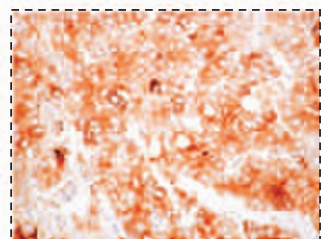

Figure I Immunohistochemical expression of Hsp-27 in TMA cores of prostatic tissues. The location of the high-magnification regions shown below each of the cores is indicated by the corresponding rectangular field. Stromal expression was not identified in any of the malignant tissues examined. No expression of Hsp-27 was identified in the nuclei although the amounts may be below the level of immunohistochemical detection. (A) Normal prostatic tissue in which luminal epithelial cells express Hsp-27 within the cytoplasm. Basal cells are scanty but, where present, are also stained. Stromal tissues are not stained. (B) Hyperplastic but not dysplastic glandular epithelium strongly expressing Hsp-27 within the cytoplasm. (C) Hyperplastic and mildly dysplastic epithelium in which basal cells are prominent and uniformly express Hsp-27. The overlying luminal epithelial cells are mainly negative, although a few express Hsp-27 strongly. (D) Hyperplastic, dysplastic and focally neoplastic intra-glandular epithelium that is predominantly negative for Hsp-27. Occasionally small foci of basal and luminal epithelial cells strongly express Hsp-27. (E) Moderately differentiated (Gleason $3+3$ ) prostatic adenocarcinoma that is negative for Hsp-27 expression. (F) Moderately differentiated (Gleason $3+3$ ) prostatic adenocarcinoma expressing Hsp-27 at a low level ( + ) in the cytoplasm of the majority of the malignant cells. (G) Poorly differentiated (Gleason $4+3$ ) prostatic adenocarcinoma expression of Hsp-27 at a high $(+++)$ level in the cytoplasm of the majority of the malignant cells. $(\mathbf{H})$ Very poorly differentiated (Gleason $5+5$ ) prostatic adenocarcinoma heterogeneously expressing Hsp27 at an intermediate level $(++)$ in the majority, but not all of the malignant cells. Magnification of all cores: $\times 60$. The detailed fields within each of the cores are magnified at $\times 200$.

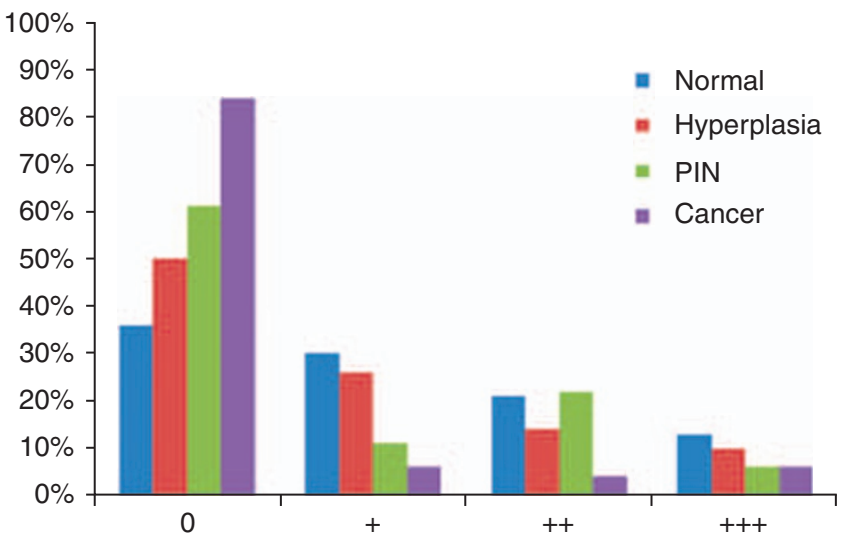

Figure 2 Numerical distribution of Hsp-27 expression by the epithelial cells in normal, hyperplastic, PIN and malignant tissues (cancer cores). The clinical behaviour of the malignant cells expressing Hsp-27 is shown in Figure 3. The,+++ and +++ signs are a conventional semi-quantitative assessment of the amount of staining defined in Figure I legend.

locomotion by a common mechanism. In fibroblasts (Hirano et al, 2004), endothelium, neutrophils and epithelial cells, phosphorylation and polymerisation of $\mathrm{Hsp}-27$ modulates transformation of
$\mathrm{G} \rightarrow \mathrm{F}$ actin (Tak et al, 2007) to generate the mechanical force required for cell motility to occur through organisation of cytoskeletal components (Doshi et al, 2009). In endothelial cells, Hsp-27 co-localises with and regulates assembly of actin filaments following phosphorylation by p38 MAP kinase (Guay et al, 1997; Landry and Huot, 1999). Thereafter, the phosphorylated and nonphosphorylated forms of Hsp-27 become differentially distributed throughout the lamellipodia, which, in the presence of fascin (Vignjevic et al, 2006), enable cell migration (Nagy et al, 2008). Non-phosphorylated Hsp-27, excluded from the leading edge of the lamellipodia, maintains short-branched actin molecules, whereas phosphorylated Hsp-27 at the base of the lamellipodia stabilises actin networks composed of long unbranched filaments (Pichon et al, 2004). When Hsp-27 phosphorylation is inhibited and functional interaction with actin impaired, migration dependent on F-actin polymerisation is prevented (Chen et al, 2009).

Enhanced levels of Hsp-27, together with its relocation from the cytoplasm to the nucleus (Wissing and Jaattela, 1996), is associated with increased resistance to apoptosis (Samali and Cotter, 1996). However, inhibition of apoptosis by Hsp-27 involves at least two parallel pathways. In the first, phosphorylated dimers of Hsp-27 interact with Daxx and block Fas-mediated apoptosis, but with no effect on Fas-induced FADD and caspase-dependent apoptosis (Charette et al, 2000). In the second, following interaction of 
Table I Relationship of Hsp-27 level with demographics and tumour characteristics

\begin{tabular}{|c|c|c|c|c|}
\hline \multirow[b]{2}{*}{ Variable } & \multirow[b]{2}{*}{$\begin{array}{c}\text { Total } \\
(n=553)\end{array}$} & \multicolumn{2}{|c|}{ Hsp-27 expression } & \multirow[b]{2}{*}{$P$-value } \\
\hline & & $\begin{array}{l}\text { Negative } \\
(n=44 I)\end{array}$ & $\begin{array}{l}\text { Positive } \\
(n=\mid 12)\end{array}$ & \\
\hline $\begin{array}{l}\text { Mean age } \pm \text { s.d. (years) } \\
\text { Mean follow-up } \pm \text { s.d. } \\
\text { (months) }\end{array}$ & $\begin{array}{r}69 \pm 5 \\
95 \pm 49\end{array}$ & $\begin{array}{c}69 \pm 5 \\
99 \pm 48\end{array}$ & $\begin{array}{c}70 \pm 5 \\
82 \pm 47\end{array}$ & $\begin{aligned} & 0.43 \\
< & 0.001\end{aligned}$ \\
\hline Early hormone management & & & & 0.21 \\
\hline Yes & 119 & $90(76 \%)$ & $29(24 \%)$ & \\
\hline No & 434 & $351(81 \%)$ & $83(19 \%)$ & \\
\hline Gleason score & & & & 0.001 \\
\hline$<7$ & 244 & $212(87 \%)$ & $32(13 \%)$ & \\
\hline$=7$ & 158 & $120(76 \%)$ & 38 (24\%) & \\
\hline$>7$ & $|5|$ & 109 (72\%) & $42(28 \%)$ & \\
\hline Clinical stage $^{a}$ & & & & 0.78 \\
\hline TI & 144 & $110(76 \%)$ & $34(24 \%)$ & \\
\hline T2 & 134 & $107(80 \%)$ & $27(20 \%)$ & \\
\hline T3 & 69 & 52 (77\%) & $15(23 \%)$ & \\
\hline Unknown & 206 & |7| (83\%) & $35(17 \%)$ & \\
\hline Baseline PSA (ng ml-1) & & & & 0.22 \\
\hline$\leqslant 4$ & 173 & 147 (85\%) & $26(15 \%)$ & \\
\hline$>4-10$ & 102 & $76(75 \%)$ & $26(25 \%)$ & \\
\hline$>10-25$ & 120 & 97 (81\%) & $23(19 \%)$ & \\
\hline$>25-50$ & 95 & $73(77 \%)$ & $22(23 \%)$ & \\
\hline$>50-100$ & 63 & $48(76 \%)$ & $15(24 \%)$ & \\
\hline Cancer in biopsy $(\%)^{b}$ & & & & 0.13 \\
\hline$\leqslant 6$ & 123 & $104(85 \%)$ & $19(15 \%)$ & \\
\hline$>6-20$ & 139 & 110 (79\%) & $29(21 \%)$ & \\
\hline$>20-40$ & 79 & 68 (86\%) & $11(14 \%)$ & \\
\hline$>40-75$ & 83 & $62(75 \%)$ & $21(25 \%)$ & \\
\hline$>75-100$ & 122 & $91(75 \%)$ & $31(25 \%)$ & \\
\hline Unknown & 7 & $6(86 \%)$ & I (14\%) & \\
\hline
\end{tabular}

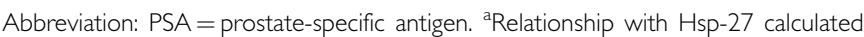

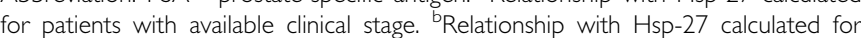
patients with available percentage of cancer in biopsy.

phosphorylated Hsp-27 with the cytochrome c/Apaf-1/dATP complex, the Fas-adaptor FADD down-regulates the procaspase 9-dependent apoptotic pathway (Gibbons et al, 2000; Jolly and Morimoto, 2000; Charette et al, 2001). In the prostate, downregulation of apoptosis is associated with elevated levels of Hsp-27, such that PC-3 and LNCaP cells become resistant to both chemicaland radiation-induced apoptosis (Gibbons et al, 2000; Jolly and Morimoto, 2000).

In non-malignant cells Hsp-27 is phosphorylated by MAP kinase p38 (Rouse et al, 1994; Huot et al, 1995), thus maintaining cellular homeostasis and integrity. Thereafter, Hsp-27 exists in an autophosphorylating signal complex together with Akt, p38 MAPK and MK2, in which Akt becomes phosphorylated on Ser $^{473}$ by MK2 (Wu et al, 2007). When Hsp-27 dissociates from the complex before Akt activation, apoptosis is induced. In androgenindependent prostate cancer, lethal progression is associated with reduced apoptosis (Berges et al, 1995) and enhanced tumour cell proliferation (McLoughlin et al, 1993; Berney et al, 2009). Mechanistically, Hsp-27 activity is regulated by post-translational phosphorylation at serine residues $\operatorname{Ser}^{15}, \operatorname{Ser}^{78}$ and $\operatorname{Ser}^{82}$ and at theonine residue $\mathrm{Thr}^{143}$ (Landry et al, 1992). However, this process appears to be promiscuous in cancer cells, being dependent on the particular kinase activation pathway invoked and the individual cell system involved. In response to extra- or intra-cellular information, signal transducer Stat 3, controlled by its inhibitor
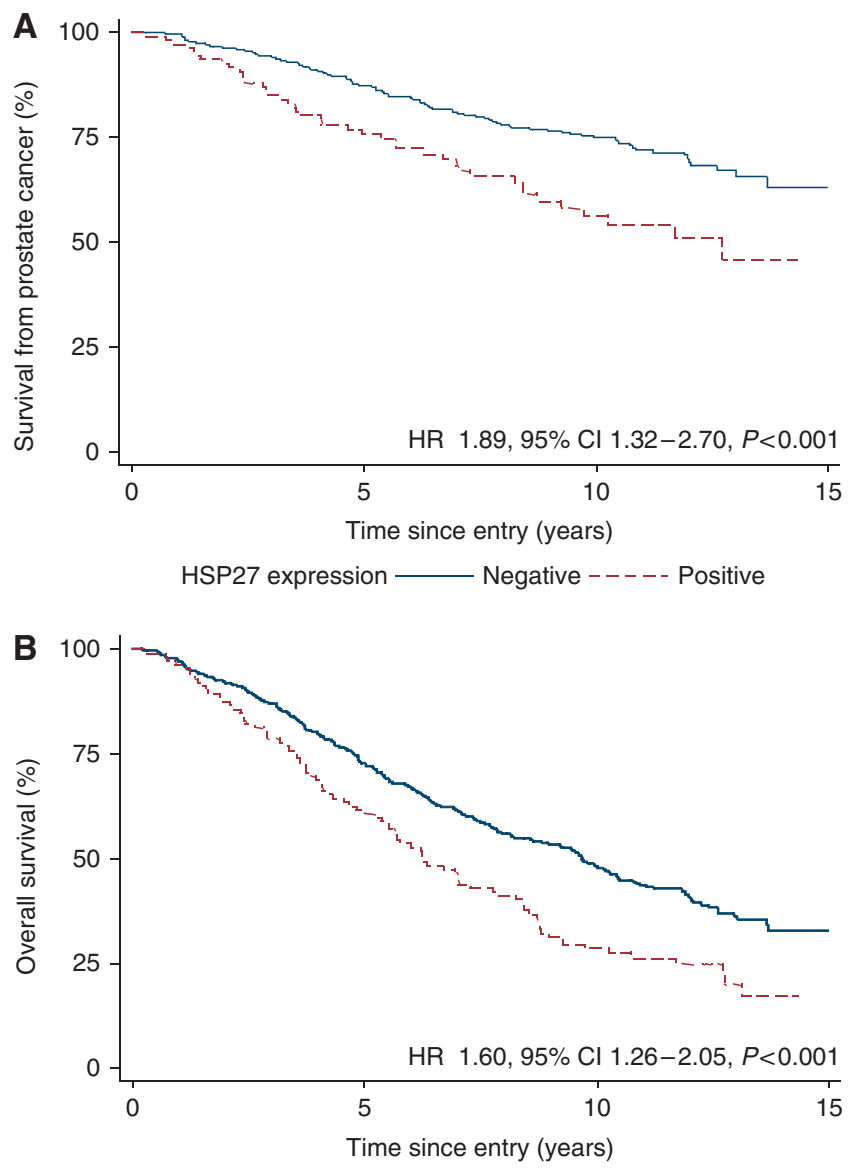

HSP27 expression - Negative - - - - - Positive

Figure 3 (A) Prostate cancer survival and (B) overall survival according to Hsp-27 expression.

DIAS3, alters genomic expression of $\mathrm{Hsp}-27$ and facilitates phosphorylation at $\operatorname{Ser}^{78}$ (Song et al, 2004).

Comparison of the distribution and intensity of Hsp-27 expression with ETS status (Clark et al, 2007, 2008; Attard et al, $2008 \mathrm{a}, \mathrm{b})$ has confirmed a statistically significant $(P>0.001)$ inverse relationship between these two parameters. As the numbers of cancers containing Ets rearrangements were similar to the numbers with Ets non-rearranged in the Hsp-27-negative group, but declined rapidly with increasing expression of Hsp-27 (Table 2), it is possible that strong expression of Hsp-27 might prevent subsequent rearrangement of Ets genes if these occur subsequent to changes in Hsp-27. With respect to behavioural phenotype, strong expression of Hsp-27 and ETS-gene rearrangement are each independently associated with aggressive and rapidly lethal prostate cancer.

Not only is Hsp-27 a powerful biomarker of aggressive prostate cancer, but it is also a potential target for novel therapeutic intervention. Studies involving antisense oligonucleotides or siRNA gene knockdown showed that Hsp-27 expression promotes androgen-independent progression of prostate cancer (Rocchi et al, 2004, 2005). Inhibition of HSPB1 expression modulated apoptosis and abrogated the malignant phenotype of human prostate cancer cells, thus identifying $\mathrm{Hsp}-27$ as a potential therapeutic target. Separately, the biphenyl isoxasole KRIBB3 inhibits tumour cell migration by blocking protein kinase C-dependent phosphorylation of Hsp27 (Shin et al, 2005) to induce mitotic arrest and to enhance apoptosis (Shin et al, 2008). Recently, it has been shown that pyrrolo-pyrimidones, a novel class of p38 MAPK/MAPK-activated protein kinase 2 (MK2) 
1142
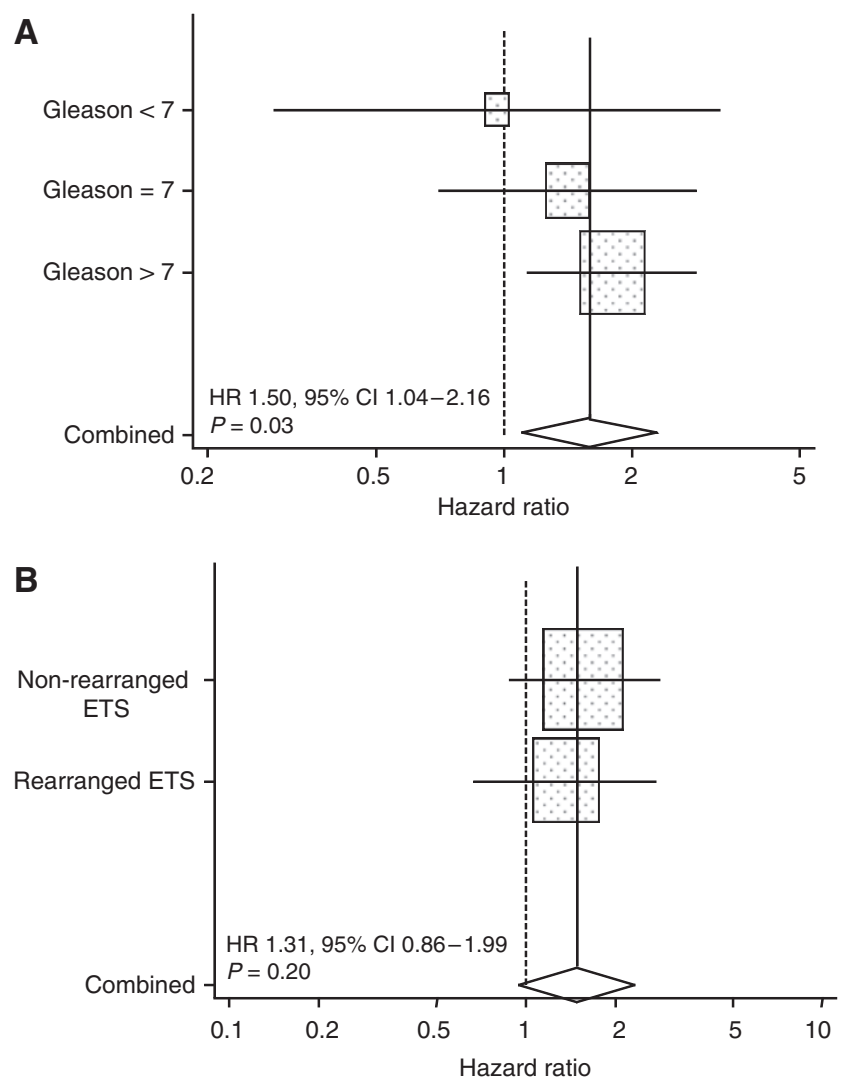

Figure 4 Forest plots indicating the effect of hazard ratios of Hsp-27 expression on prostate cancer survival in a Cox multivariate model by (A) Gleason subgroups and (B) ETS subgroups. The graph shows for each subgroup the hazard ratio with the $95 \%$ confidence interval and the percentage weight contributed to the meta-analysis by each subgroup is shown by the size of the corresponding rectangle. The summary hazard ratio is shown by the solid line and the middle of the diamond, the extremes of which represent the $95 \%$ confidence intervals. The dotted line shows the no effect point.

inhibitors, inhibit phosphorylation of Hsp-27, its downstream target (Schlapbach et al, 2008), and that inhibition of Hsp-27 phosphorylation at $\mathrm{Ser}^{78}$ and $\mathrm{Ser}^{82}$ by the MAPKAP kinase MK5 prevents the F-actin reorganisation that is necessary for cell migration (Kostenko et al, 2009). Not only is the MAPKAPK2/ Hsp-27 pathway a promising potential target for therapeutic intervention, but the isoflavone genistein, an oestrogen analog
Table 2 Association of Hsp-27 and ETS

\begin{tabular}{lcc}
\hline & \multicolumn{3}{c}{ ETS status } \\
\cline { 2 - 3 } Hsp-27 & Normal & Rearranged \\
\hline Negative & $185(54 \%)$ & $156(46 \%)$ \\
+ & $19(53 \%)$ & $17(47 \%)$ \\
++ & $23(88 \%)$ & $3(12 \%)$ \\
+++ & $32(100 \%)$ & $0(-)$ \\
\hline Statistical analysis: & $\chi^{2}$ (trend) $=31.4, P<0.001 ; \chi^{2}$ (positive vs negative) $=\mid 8.3$,
\end{tabular}

$P<0.001$.

and candidate chemotherapeutic agent, inhibits cell migration by blocking activation of this pathway ( $\mathrm{Xu}$ and Bergan, 2006), emphasising the validity of this proposed therapeutic approach.

This study analysing the largest cohort yet reported of conservatively managed patients with prostate cancer for more than 15 years has shown the accuracy of Hsp-27 expression as a prognostic biomarker of aggressive disease at initial diagnosis. Further, the analysis indicates two divergent phenotypes of lethal prostate cancer involving either ETS rearrangement or high Hsp-27 expression. These findings are of biological interest not only for studying the initiation and progression of prostate cancer but also for clinically identifying men who require immediate aggressive management to control potentially lethal disease. As this is a relatively small subset $(\sim 25-35 \%)$ of men diagnosed with prostate cancer, use of this biomarker provides the biological rationale to focus the available resources on actively treating this high-risk group, while allowing the majority of prostate cancer patients $(\sim 65-75 \%)$ to be managed conservatively.

\section{ACKNOWLEDGEMENTS}

This work was funded by Cancer Research UK, National Cancer Research Institute, a specialised program of Research Excellence grant from the US National Cancer Institute, Grand Charity of Freemasons, Rosetrees Trust, The Bob Champion Cancer Trust, The Orchid Appeal, David Koch Foundation and North West Cancer Research Fund. Funding bodies had no involvement in the design and conduct of the study; in collection management, analysis and interpretation of the data; or in preparation, review and approval of the paper. We thank Jill Gosney for her assistance in preparing this paper.

\section{REFERENCES}

Adams DJ, Hajj H, Edwards DP, Bjercke RJ, McGuire WL (1983) Detection of a $\mathrm{Mr} 24,000$ estrogen-regulated protein in human breast cancer by monoclonal antibodies. Cancer Res 43: 4297-4301

Adolfsson J, Steineck G, Hedlund P-O (1997) Deferred treatment of clinically localized low-grade prostate cancer: actual 10-year and projected 15-year follow-up of the Karolinska series. Urology 50: $722-726$

Albertsen P, Hanley JA, Fine J (2005) 20-year outcomes following conservative management of clinically localized prostate cancer. JAMA 293: $2095-2101$

Albertsen PC, Fryback DG, Storer BE, Kolon TF, Fine J (1995) Long-term survival among men with conservatively treated localized prostate cancer. JAMA 274: 626-631

Attard G, Clark J, Ambroisine L, Fisher G, Kovacs G, Flohr P, Berney D, Foster CS, Fletcher A, Gerald WL, Moller H, Reuter V, De Bono JS, Scardino P, Cuzick J, Cooper CS (2008a) Duplication of the fusion of TMPRSS2 to ERG sequences identifies fatal human prostate cancer. Oncogene 27: 253-263
Attard G, Clark J, Ambroisine L, Mills IG, Fisher G, Flohr P, Reid A, Edwards S, Kovacs G, Berney D, Foster CS, Massie CE, Fletcher A, De Bono JS, Scardino P, Cuzick J, Cooper CS, Transatlantic Prostate Group (2008b) Heterogeneity and clinical significance of ETV1 translocations in human prostate cancer. Br J Cancer 99: 314-320

Berges RR, Vucanovic J, Epstein JI, Carmichel M, Cisek L, Johnson DE, Veltri RN, Walsh PC, Isaacs JT (1995) Implication of cell kinetic changes during progression of human prostatic cancer. Clin Cancer Res 1: $473-480$

Berney DM, Fisher G, Kattan MW, Oliver RTD, Moller H, Fearn P, Eastham J, Scardino P, Cuzick J, Reuter VE, Foster CS (2007a) Major shifts in the treatment and prognosis of prostate cancer due to changes in pathological diagnosis and grading. BJU Int 100: $1240-1244$

Berney DM, Fisher G, Kattan MW, Oliver RTD, Moller H, Fearn P, Eastham J, Scardino P, Cuzick J, Reuter VE, Foster CS (2007b) Pitfalls in the diagnosis of prostate cancer: retrospective review of 1791 cases with clinical outcome. Histopathology 51: $452-457$ 
Berney DM, Gopalan A, Kudahetti S, Fisher G, Ambroisine L, Foster CS, Reuter V, Eastham J, Moller H, Kattan MW, Gerald W, Cooper C, Scardino P, Cuzick J, for the Trans-Atlantic Prostate Group (2009) Ki-67 and outcome in clinically localised prostate cancer: analysis of conservatively treated prostate cancer patients from the Trans-Atlantic Prostate Group study. Br J Cancer 100(6): 888-893

Bill-Axelson A, Holmberg L, Ruutu M, Haggman M, Anderson SO, Bratell S, Spangberg A, Busch C, Nordling S, Garmo H, Palmgren J, Adami HO, Norlen BJ, Johansson JE, Scandinavian Prostate Cancer Group Study No. 4 (2005) Radical prostatectomy versus watchful waiting in early prostate cancer. N Engl J Med 352: 1977-1984

Carver BS, Tran J, Chen Z, Carracedo-Perez A, Alimonti A, Nardella C, Gopalan A, Scardino PT, Cordon-Cardo C, Gerald W, Pandolfi PP (2009) ETS rearrangements and prostate cancer inhibition. Nature 457: 7231

Cerveira N, Ribeiro FR, Peixoto A, Costa V, Henrique R, Jeronimo C, Teixeira MR (2006) TMPRSS2-ERG gene fusion causing ERG overexpression precedes chromosome copy number changes in prostate carcinomas and paired HGPIN lesions. Neoplasia 8: 826-832

Charette SJ, Lambert H, Landry J (2001) A kinase-independent function of Ask1 in caspase-independent cell death. J Biol Chem 276: 36071-36074

Charette SJ, Lavoie JN, Lambert H, Landry J (2000) Inhibition of Daxx-mediated apoptosis by heat shock protein 27. Mol Cell Biol 20: $7602-7612$

Chen HF, Xie LD, Xu CS (2009) Role of heat shock protein 27 phosphorylation in migration of vascular smooth muscle cells. Mol Cell Biochem 327(1-2): 1-6

Chodak GW, Kranc DM, Puy LA, Takeda H, Johnson K, Chang C (1992) Nuclear localization of androgen receptor in heterogeneous samples of normal, hyperplastic and neoplastic human prostate. J Urol 147: 798 - 803

Clark J, Attard G, Jhavar S, Flohr P, Reid A, De-Bono J, Eeles R, Scardino P, Cuzick J, Fisher G, Parker MD, Foster CS, Berney D, Kovacs G, Cooper CS (2008) Complex patterns of ETS gene alteration arise during cancer development in the human prostate. Oncogene 27: 1993-2003

Clark J, Merson S, Flohr P, Edwards S, Foster CS, Eeles R, Martin FL, Phillips DH, Crundwell M, Christmas T, Thompson A, Fisher C, Kovacs G, Cooper CS (2007) Diversity of TMPRSS2-ERG fusion transcripts in the human prostate. Oncogene 26: 2667-2673

Cornford PA, Dodson AR, Parsons KF, Fordham M, Desmond AD, Woolfenden A, Neoptolemos JP, Foster CS (2000) Heat shock protein (HSP) expression independently predicts clinical outcome in prostate cancer. Cancer Res 60: 7099-7105

Cox DR, Oakes D (1984) Analysis of Survival Data. Chapman and Hall: London, New York

Cuzick J, Fisher G, Kattan MW, Berney D, Oliver T, Foster CS, Moller H, Reuter V, Fearn P, Eastham J, Scardino P, Transatlantic Prostate Group (2006) Long-term outcome among men with conservatively treated localised prostate cancer. Br J Cancer 95: 1186-1194

Deshmukh N, Foster CS (1997) Grading prostate cancer. In Pathology of the Prostate Foster CS, Bostwick DG (eds) Vol. 34, Chapter 11, pp 191-227. WB Saunders: Philadelphia

Doshi BM, Hightower LE, Lee J (2009) The role of Hsp27 and actin in the regulation of movement in human cancer cells responding to heat shock. Cell Stress Chaperones 14: 445-457

Eastham MA, Kattan MW, Fearn P, Fisher G, Berney DM, Oliver T, Foster CS, Moller H, Reuter V, Cuzick J, Scardino P (2008) Local progression among men with conservatively treated localized prostate cancer: results from the Transatlantic Prostate Group. Eur Urol 53: 347-354

Foster CS (2000) Pathology of benign prostatic hyperplasia. Prostate 9: $4-14$

Foster CS, Bostwick DG, Bonkoff H, Damber J-E, Van der Kwast T, Montironi R, Sakr W (2000) Cellular and molecular pathology of prostate cancer precursors. Scand J Urol Nephrol 34(Suppl 205): 19-43

Foster CS, Dodson A, Karavana V, Smith PH, Ke Y (2002) Prostatic stem cells. J Pathol 197: 551 - 565

Foster CS, Falconer A, Dodson AR, Norman AR, Dennis A, Fletcher A, Southgate C, Dowe A, Dearnaley D, Jhavar S, Eeles R, Feber A, Cooper CS (2004) Transcription factor E2F3 overexpressed in prostate cancer independently predicts clinical outcome. Oncogene 23: 5871-5879

Gibbons NB, Watson RWG, Coffey RNT, Brady HP, Fitzpatrick JM (2000) Heat-shock proteins inhibit induction of prostate cancer cell apoptosis. Prostate 45: 58-65

Glaessgen A, Jonmarker S, Lindberg A, Nilsson B, Lewensohn R, Ekman P, Valdman A, Egevad L (2008) Heat shock proteins 27, 60 and 70 as prognostic markers of prostate cancer. APMIS 116: 888-895
Guay J, Lambert H, Gingras-Breton G, Lavoie JN, Huot J, Landry J (1997) Regulation of actin filament dynamics by p38 map kinase-mediated phosphorylation of heat shock protein 27. J Cell Sci 110: 357-368

Hirano S, Shelden EA, Gilmont RR (2004) HSP27 regulates fibroblast adhesion, motility and matrix contraction. Cell Stress Chaperones 9: 29-37

Holmberg L, Bill-Axelson A, Helgesen F, Salo JO, Folmerz P, Haggman M, Andersson SO, Spangberg A, Busch C, Nordling S, Palmgren J, Adami HO, Johansson JE, Norlen BJ (2002) A randomized trial comparing radical prostatectomy with watchful waiting in early prostate cancer. N Engl J Med 347: 781 - 789

http://info.cancerresearchuk.org/cancerstats/types/prostate/

Huot J, Lambert H, Lavoie JN, Guimond A, Houle F, Landry J (1995) Characterization of $45-\mathrm{kDa} / 54-\mathrm{kDa}$ HSP27 kinase, a stress sensitive kinase which may activate the phosphorylation-dependent protective function of mammalian $27-\mathrm{kDa}$ heat shock protein HSP27. Eur J Biochem 227: $416-427$

Jemal A, Siegel R, Ward E, Hao Y, Xu J, Murray T, Thun MJ (2008) Cancer statistics 2008. CA Cancer J Clin 58: 71-96

Johansson JE, Andren O, Andersson SO, Dickman PW, Holmberg L, Magnuson A, Adami HO (2004) Natural history of early, localized prostate cancer. JAMA 291: 2713-2719

Jolly C, Morimoto RI (2000) Role of the heat shock response and molecular chaperones in oncogenesis and cell death. J Natl Cancer Inst 92: $1564-1572$

Kostenko S, Johannessen M, Moens U (2009) PKA-induced F-actin rearrangement requires phosphorylation of $\mathrm{Hsp} 27$ by the MAPKAP kinase MK5. Cell Signal 21(5): $712-718$

Landry J, Huot J (1999) Regulation of actin dynamics by stress-activated protein kinase 2 (SAPK2)-dependent phosphorylation of heat-shock protein of $27 \mathrm{kDa}$ (Hsp27). Biochem Soc Symp 64: 79-89

Landry J, Lambert H, Zhou M, Lavoie JM, Hickey E, Weber LA, Anderson CW (1992) Human HSP27 is phosphorylated as serines 78 and serines 82 by heat shock and mitogen-activated kinases that recognize the same amino acid motif as S6 kinase II. J Biol Chem 267: 794-803

McLoughlin J, Foster CS, Price P, WIlliams G, Abel PD (1993) Evaluation of $\mathrm{Ki}-67$ monoclonal antibody as prognostic indicator for prostatic carcinoma. Br J Urol 72: $92-97$

Miyake H, Muramaki M, Kurahashi T, Takenaka A, Fujisawa M (2008) Expression of potential molecular markers in prostate cancer: correlation with clinicopathological outcomes in patients undergoing radical prostatectomy. Urol Oncol (Epub ahead of print), doi:10.1016/j.urolonc. 2008.08.001

Morino M, Tsuzuki T, Ishikawa Y, Shirakami T, Yoshimura M, Kiyosuke Y, Matsunaga K, Yoshikumi C, Saijo N (1997) Specific expression of HSP27 in human tumour cell lines in vitro. In Vivo 11: 179-184

Mosquera JM, Perner S, Genega EM, Sanda M, Hofer MD, Mertz KD, Paris PL, Simko J, Bismar TA, Ayala G, Shah RB, Loda M, Rubin MA (2008) Characterization of TMPRSS2-ERG fusion high-grade prostatic intraepithelial neoplasia and potential clinical implications. Clin Cancer Res 14: $3380-3385$

Nagy S, Ricca BL, Norstrom MF, Courson DS, Brawley CM, Smithback PA, Rock RS (2008) A myosin motor that selects bundles actin for motility. Proc Natl Acad Sci USA 105: 9616-9620

O'Neill PAO, Shaaban AM, West CR, Dodson A, Jarvis C, Moore P, Davies MPA, Sibson DR, Foster CS (2003) Increased risk of malignant progression in benign proliferating breast lesions defined by expression of heat shock protein 27. Br J Cancer 90: $182-188$

Ono A, Kumai T, Koizumi H, Nishikawa H, Kobayashi S, Tadokoro M (2009) Overexpression of heat shock protein 27 in squamous cell carcinoma of the uterine cervix: a proteomic analysis using archival formalin-fixed, paraffin-embedded tissues. Hum Pathol 40: 41-49

Parkin DM, Bray F, Ferlay J, Pisani P (2005) Global science statistics. CA Cancer J Clin 55: 74-108

Perner S, Mosquera JM, Demichelis F, Hofer MD, Paris PL, Simko J, Collins C, Bismar TA, Chinnaiyan AM, De Marzo AM, Rubin MA (2007) TMPRSS2-ERG fusion prostate cancer: an early molecular event associated with invasion. Am J Surg Pathol 31: 882-888

Pichon S, Bryckaert M, Berrou E (2004) Control of actin dynamics by p38 MAP kinase - Hsp27 distribution in the lamellipodium of smooth muscle cells. J Cell Sci 117: 2569-2577

Rocchi P, Beraldi E, Ettinger S, Fazli L, Vessella RL, Nelson C, Gleave M (2005) Increased Hsp27 after androgen ablation facilities androgenindependent progression in prostate cancer via signal transducers and activators of transcription 3-mediated suppression of apoptosis. Cancer Res 65: $11083-11093$ 
Rocchi P, So A, Kojima S, Signaevsky M, Beraldi E, Fazli L, Hurtado-Coll A Yamanaka K, Gleave M (2004) Heat shock protein 27 increases after androgen ablation and plays a cytoprotective role in hormone-refractory prostate cancer. Cancer Res 64: 6595-6602

Rouse J, Cohen P, Trigon S, Morange M, Alonso-Llamazares A, Zamanillo D, Hunt T, Nebreda AR (1994) A novel kinase cascade triggered by stress and heat shock that stimulates MAPKAP kinase-2 and phosphorylation of the small heat shock proteins. Cell 78: $1027-1037$

Samali A, Cotter TG (1996) Heat shock proteins increase resistance to apoptosis. Exp Cell Res 223: $163-170$

Schlapbach A, Feifel R, Hawtin S, Heng R, Koch G, Moebitz H, Revesz L, Scheufler C, Velcicky J, Waelchli R, Huppertz C (2008) Pyrrolopyrimidones: a novel class of MK2 inhibitors with potent cellular activity. Bioorg Med Chem Lett 18: 6142-6146

Shi P, Wang MM, Jiang LY, Liu HT, Sun JZ (2008) Paclitaxel-doxorubicin sequence is more effective in breast cancer cells with heat shock protein 27 overexpression. Chin Med J (Engl) 121: 1975-1979

Shin KD, Lee MY, Shin DS, Lee S, Son KH, Koh S, Paik YK, Kwon BM, Han DC (2005) Blocking tumor cell migration and invasion with biphenyl isoxazole derivative KRIBB3, a synthetic molecule that inhibits Hsp27 phorphorylation. J Biol Chem 280: 41439-41448

Shin KD, Yoon YJ, Kang YR, Son KH, Kim HM, Kwon BM, Han DC (2008) KRIBB3, a novel microtubule inhibitor, induces mitotic arrest and apoptosis in human cancer cells. Biochem Pharmacol 75: 383-394

Song H, Ethier SP, Dziubinski ML, Lin J (2004) Stat3 modulates heat shock $27 \mathrm{kDa}$ protein expression in breast epithelial cells. Biochem Biophys Res Commun 314: $143-150$

Tak H, Jang E, Kim SB, Park J, Suk J, Yoon YS, Ahn JK, Lee JH, Joe CO (2007) 14-3-3epsilon inhibits MK5-mediated cell migration by disrupting F-actin polymerization. Cell Signal 19: 2379-2387

Tenniswood MP, Guenette RS, Lakins J, Mooibroek M, Wong P, Welsh JE (1992) Active cell death in hormone-dependent tissues. Cancer Metastasis Rev 11: $197-220$

Tetu B, Brisson J, Landry J, Huot J (1995) Prognostic significance of heatshock protein-27 in node-positive breast carcinoma: an immunohistochemical study. Breast Cancer Res Treat 36: 93-97

Tomlins SA, Laxman B, Varambally S, Cao X, Yu J, Helgeson BE, Cao Q, Prensner JR, Rubin MA, Shah RB, Mehra R, Chinnaiyan AM (2008)
Role of the TMPRSS2-ERG gene fusion in prostate cancer. Neoplasia 10: $177-188$

Tomlins SA, Rhodes DR, Perner S, Dhanasekaran SM, Mehra R, Sun X-W, Varambally S, Cao X, Tchinda J, Kuefer R, Lee C, Montie JE, Shah RB, Pienta KJ, Rubin MA, Chinnaiyan AM (2005) Recurrent fusion of TMPRSS2 and ETS transcription factor genes in prostate cancer. Science 310: $644-648$

Tsuruta M, Nishibori H, Hasegawa H, Ishil Y, Endo T, Kubota T, Kitajima M, Kitagawa Y (2008) Heat shock protein 27, a novel regulator of 5-fluorouracil resistance in colon cancer. Oncol Rep 20: 1165-1172

van Diest PJ, van Dam P, Henzen-Logmans SC, Berns E, van der Burg MEL, Green J, Vergote I (1997) A scoring system for immunohistochemical staining: consensus report of the task force for basic research of the EORTC-GCCG. J Clin Pathol 50: $801-804$

Vignjevic D, Kojima S, Aratyn Y, Danciu O, Svitkinas T, Borisy GG (2006) Role of fascin in filopodial protrusion. J Cell Biol 174: 863-875

Wang J, Cai Y, Yu W, Ren C, Spencer DM, Ittmann M (2008) Pleiotropic biological activities of alternatively spliced TMPRSS2/ERG fusion gene transcripts. Cancer Res 68: 8516-8524

Wissing D, Jaattela M (1996) HSP27 and HSP70 increase the survival of WEHI-S cells exposed to hyperthermia. Int J Hyperthermia 12: 125-138

Wu R, Kausar H, Johnson P, Montoya-Durango DE, Merchant M, Rane MJ (2007) Hsp27 regulates Akt activation and polymorphonuclear leukocyte apoptosis by scaffolding MK2 to Akt signal complex. J Biol Chem 282: 21598-21608

Xu L, Bergan RC (2006) Genistein inhibits matrix metalloproteinase type 2 activation and prostate cancer cell invasion by blocking the transforming growth factor beta-mediated activation of mitogen-activated protein kinase-activated protein kinase $2-27-\mathrm{kDa}$ heat shock protein pathway. Mol Pharmacol 70: $869-877$

Yang YX, Sun XF, Cheng AL, Zhang GY, Yi H, Sun Y, Hu HD, Hu P, Ye F, Chen ZC, Xiao ZQ (2009) Increased expression of HSP27 linked to vincristine resistance in human gastric cancer cell line. J Cancer Res Clin Oncol 135: $181-189$

Zoubeidi A, Zardan A, Beraldi E, Fazli L, Sowery R, Rennie P, Nelson C, Gleave M (2007) Cooperative interactions between androgen receptor (AR) and heat shock protein 27 facilitate AR transcriptional activity. Cancer Res 67: $10455-10465$ 